\title{
UV Visible Spectrophotometric Determination of the Quality of Antiretroviral Drugs Distributed in Kinshasa
}

\author{
Erick Ntambwe Kamangu1", Jérémie K. Mbinze ${ }^{2,3 \#, ~ A r n o l d ~ M . ~ M i n g u 3 ~}{ }^{3}$, Jacquie B. Bolavie4, \\ Georges Lelo Mvumbi ${ }^{1}$, Richard Lunganza Kalala', Gauthier Kahunu Mesia ${ }^{5}$, \\ Mariano Lusakibanza ${ }^{5}$, Jean Mavar ${ }^{3}$, Roland D. Marini² ${ }^{*}$
}

\begin{abstract}
${ }^{1}$ Laboratory of Molecular Biochemistry, Department of Basic Sciences, Faculty of Medicine, University of Kinshasa, Kinshasa, Democratic Republic of Congo

${ }^{2}$ Laboratory of Analytical Chemistry, CIRM, Department of Pharmacy, University of Liège, Liège, Belgium

${ }^{3}$ Laboratory of Analytical Pharmaceutical, Department of Galenic and Drugs Analysis, Faculty of Pharmaceutical Sciences, University of Kinshasa, Kinshasa, Democratic Republic of Congo

${ }^{4}$ Laboratory Service, Institute of Research in Science of Health, Kinshasa, Democratic Republic of Congo

${ }^{5}$ Unit of Clinical Pharmacology, Department of Pharmacology, Faculties of Medicine and Pharmaceutical Sciences, University of Kinshasa, Kinshasa, Democratic Republic of Congo

Email: ^rmarini@ulg.ac.be
\end{abstract}

How to cite this paper: Kamangu, E.N., Mbinze, J.K., Mingu, A.M., Bolavie, J.B., Mvumbi, G.L., Kalala, R.L., Mesia, G.K., Lusakibanza, M., Mavar, J. and Marini, R.D. (2017) UV Visible Spectrophotometric Determination of the Quality of Antiretroviral Drugs Distributed in Kinshasa. Open Access Library Journal, 4: e2923. https://doi.org/10.4236/oalib.1102923

Received: January 5, 2017

Accepted: February 12, 2017

Published: February 15, 2017

Copyright $\odot 2017$ by authors and Open Access Library Inc.

This work is licensed under the Creative Commons Attribution International License (CC BY 4.0).

http://creativecommons.org/licenses/by/4.0/ (c) (i) Open Access

\begin{abstract}
Background: Antiretrovirals (ARVs) are the molecules used in the fight against infection by the Human Immunodeficiency Virus (HIV). Their main objective is to stop the virus from replicating and thus allow the immune system to recover. In 2001, the program to fight against HIV/AIDS United Nations (UNAIDS) and its partners has decided to strengthen the pharmaceutical channel and improve access to good quality care. Thus ARV quality control is recommended. Objective: The objective of this work was to monitor the quality of ARVs distributed in Kinshasa. Methodology: In this work, UV-visible spectrophotometry is used for the analysis of ARVs presented in simple form distributed in the city of Kinshasa. Results: The results of this work show that the stated and analyzed ARVs contain active ingredients; there is no placebo. Ten percent of these ARVs are non-compliant with regard to dosing of the active test. Conclusion: These results confirm the need to control these drugs to protect patients from adverse consequences related to their poor quality.
\end{abstract}

\section{Subject Areas}

Biochemistry, Molecular Biology 


\section{Keywords}

Spectrophotometry, UV-Visible, ARV, Kinshasa

\section{Introduction}

Antiretrovirals (ARVs) are molecules used to fight against the Human Immunodeficiency Virus (HIV) infection [1]. The main objective of these molecules is to slow down the virus replication and thus allow the immune system to recover, to make the plasmatic Viral Load (VL) undetectable ( $<50 \mathrm{RNA} / \mathrm{ml}$ copies) which allows better immune restoration and reduces the risk of selection of resistant virus [1].

In 2001, the United Nations program to fight against HIV/AIDS (UNAIDS) and its partners has addressed the problems of drug quality in their generic form [2]. This program is more interested in ARV in resource limited countries where generics are often of dubious quality and quantitatively under dosage recommendation [2] [3]. UNAIDS has decided to strengthen the pharmaceutical channel of these countries and improve access to quality care for all patients because poverty and disorganization of the pharmaceutical sector are the main reasons for the phenomenon of counterfeiting [4]. The qualitative and quantitative analysis of ARV is therefore recommended. This must be done regularly, internally and externally, and be reported to the appropriate authorities [1]. It should be performed throughout the pharmaceutical supply circuit; from manufacture to use. At reception and storage point, each batch of ARVs must be subject to quality control [1].

The National Programs against HIV/AIDS (PNMLS and PNLS) are the main national bodies in the fight against the epidemic and the care of People Living with HIV (PLHIV) in the country. Their main strategies are focused on education and outreach; free voluntary testing in different centers, management, therapeutic monitoring and psychosocial assistance for eligible patients [5].

In the Democratic Republic of Congo (DRC), the most commonly used molecules, as of 2012, are: Abacavir (ABC), Efavirenz (EFV), Lamivudine (3TC), Lopinavir boosted by Ritonavir (LPV/r), Nevirapine (NVP), Stavudine (d4T) and Zidovudine (ZDV) [5]. All these molecules are pre-qualified generic by the World Health Organization (WHO); however, pre-qualification does not exclude quality control in the provision for use by the patient [2].

This study aimed to control the quality of some ARVs distributed in Kinshasa [6]. The targeted molecules in this study were: Abacavir (ABC), Efavirenz (EFV), Nevirapine (NVP) and Zidovudine (ZDV).

\section{Materials and Methods}

\subsection{Framework}

This study was conducted in the period from the August 20, 2013 to January, 20 
2014. Quality control analyses were performed at Laboratory of Molecular Biology of the Faculty of Medicine of the University of Kinshasa (UNIKIN), LAPHAKI and AVEPHARMA Laboratories, all in Kinshasa.

\subsection{Analyzed Molecules}

The molecules analyzed in this study are presented in Table 1 . They were freely donated by different monitoring centers for HIV patients in Kinshasa [5].

\subsection{Selection of Samples}

The sample selection was made randomly in the received packages. Twenty pills of each drug were used for the analysis.

\subsection{Materials}

The UV-Visible spectrophotometer (HP/Agilent 8453) with Agilent Technologies ChemStation software (Gyeonggi-do, South Korea) was used for the study. The wavelengths used were $285 \mathrm{~nm}$ for Abacavir (ABC) [7] and Nevirapine (NVP) [7] [8], $266 \mathrm{~nm}$ for Zidovudine (ZDV) [7] [9] and $254 \mathrm{~nm}$ for Efavirenz (EFV) [7]. Friabilimeter was of Erweka brand and tablet disintegration was achieved with a device of the Labfine model Dit-200 brand from Research Lab Fine Chem (Mumbai, India).

Table 1. List of Antiretrovirals used in this study.

\begin{tabular}{|c|c|c|c|c|}
\hline $\begin{array}{l}\text { NOM DU MEDICAMENT } \\
\text { (SPECIALITE) }\end{array}$ & D C I & Manufacturer & $\begin{array}{c}\text { Batch } \\
\text { Number }\end{array}$ & $\begin{array}{c}\text { Origin of } \\
\text { Manufacturer }\end{array}$ \\
\hline $\begin{array}{l}\text { Abacavir sulfate } \\
\text { Pills of } 300 \mathrm{mg}\end{array}$ & Abacavir & $\begin{array}{l}\text { Matrix labo } \\
\text { Limited }\end{array}$ & 1082374 & India \\
\hline $\begin{array}{l}\text { Abacavir sulfate } \\
\text { Pills of } 300 \mathrm{mg}\end{array}$ & Abacavir & Aurobindo & AB3011030A & India \\
\hline $\begin{array}{l}\text { Abacavir sulfate } \\
\text { Pills of } 300 \mathrm{mg}\end{array}$ & Abacavir & $\begin{array}{c}\text { Aurobindo } \\
\text { pharma limited }\end{array}$ & $\begin{array}{c}\text { NDC } \\
65862-073-60\end{array}$ & India \\
\hline $\begin{array}{c}\text { Aviroz }^{\circledR} \\
\text { Pills of } 300 \mathrm{mg}\end{array}$ & Zidovudine & Ranbaxy & 2359701 & India \\
\hline $\begin{array}{c}\text { EstivaN }^{\circledR} \\
\text { Pills of } 600 \mathrm{mg}\end{array}$ & Efavirenz & $\begin{array}{c}\text { Hétéro labs } \\
\text { Iimited }\end{array}$ & E120314A & India \\
\hline $\begin{array}{c}\text { Nevipan } \\
\text { Pills of } 200 \mathrm{mg}\end{array}$ & Nevirapine & Ranbaxy & 2386326 & India \\
\hline $\begin{array}{c}\text { Nevimune }^{\circledR} \\
\text { Pills of } 200 \mathrm{mg}\end{array}$ & Nevirapine & Cipla & X10889 & India \\
\hline $\begin{array}{c}\text { Nevirapine } \\
\text { Pills of } 200 \mathrm{mg}\end{array}$ & Nevirapine & $\begin{array}{l}\text { Strides arcolab } \\
\text { Limited }\end{array}$ & 7216002 & India \\
\hline $\begin{array}{c}\text { Nevirapine } \\
\text { Pills of } 200 \mathrm{mg}\end{array}$ & Nevirapine & Strides & NE2012089-A & India \\
\hline $\begin{array}{c}\text { Nevirapine } \\
\text { Pills of } 200 \mathrm{mg}\end{array}$ & Nevirapine & Aurobindo & NE2012089-A & India \\
\hline
\end{tabular}




\subsection{Reagents}

The substances of references used were obtained from Sigma Aldrich of Belgium (Efavirenz-98.1\% and Zidovudine-98.0\%), USP Millipore (Nevirapine-99.7\%) and Cayman Chemical Lansing of the United States of America (Abacavir-100\%). Methanol and methylene chloride used for these analyzes were provided by Merck of Germany. The ultrapure water was produced using the Aqua Max-Basic 360 series device of YL Instruments of South Korea.

\subsection{Pharmaco-Technical Tests}

Performed according to the recommendations of the European Pharmacopoeia $8.1[10]$, the friability test was performed by weighing a given number of pills equivalent to $6.5 \mathrm{~g}$. This assay allows estimating the strength of the tablets during the packaging operations, and possible coating and transport. The pills disintegration was completed in ultrapure water placed at $37^{\circ} \mathrm{C}$ for 15 minutes to determine the ability to disintegrate in a prescribed time in liquid medium.

\subsection{Methods}

The friability assays, the chemo-physical assays and the spectrophotometric assays used in this study are all described in the literature [6]-[14]. The standards assay being set from $90.0 \%$ to $110.0 \%$.

\subsection{Preparation of Standard Solutions}

Standard solutions of $1 \mathrm{mg} / \mathrm{ml}$ were prepared from the reference chemicals of different molecules each dissolved in $100 \mathrm{ml}$ of solvent (methanol for EFV, NVP and ZDV; ultrapure water for ABC). Different concentrations ( $5 \mu \mathrm{g} / \mathrm{ml}, 10 \mu \mathrm{g} / \mathrm{ml}$ and $15 \mu \mathrm{g} / \mathrm{ml}$ ) were used to draw the calibration line in the type of $\mathrm{y}=\mathrm{ax}+\mathrm{b}(\mathrm{a}$ : as the slope of the equation; $\mathrm{b}$ : as origin coordinate; $\mathrm{x}$ : as the concentration; $\mathrm{y}$ : as the analytical response or absorbance). The coefficient of determination $\left(\mathrm{R}^{2}\right)$ was used as a quality indicator for the calibration slope. After the linearity of the calibration slope was confirmed, it was used to calculate the sample concentrations.

\section{Results and Discussion}

The samples used in this study were provided without charge by different centers of treatment and supported for People Living with HIV/AIDS in Kinshasa. Table 1 provides information on the various molecules used; he presents the name of the drug, the International Nonproprietary Name (INN), the manufacturer's name, the batch number and the manufacturer's country of origin. All these molecules are manufactured by Indian pharmaceutical companies (Matrix Lab Limited, Aurobindo Pharma Limited, Ranbaxy, Hetero Labs Limited, Cipla and Strides Arcolab Limited).

Table 2 shows the results of tests friability obtained for the 10 analyzed specialties. All molecules were analyzed in accordance with a loss of weight less than $1 \%$ by. These tablets can therefore hold up well during packaging and transpor- 
tation.

Table 3 presents the results of the disintegration test of the 10 molecules tested. This Physicochemical test provides information on the potential release of active ingredient from the oral dosage form in a required time and good disintegration of such tablets in the gastrointestinal tract because the disintegration promotes bioavailability of drug [6] [10]. These molecules were compliant in relation to disaggregation time; they all have a time inferior than 15 minutes.

Further then, the molecules were identified through their Ultra Violet (UV) spectra through the methods used. These UV spectra are shown in Figure 1 for all 4 analyzed molecules. In all samples tested, there was concordance between the standard UV spectrum and that found in the sample, allowing confirming the identity of the different molecules analyzed. They all contain the active principle as declared by the manufacturer.

After determination of UV spectra, the molecules were quantified using the calibration lines. The results of the quantification of the molecules are shown in

Table 2. Results of the friability assays with the studied drugs.

\begin{tabular}{cc}
\hline Specialties & Obtained \% \\
\hline Nevipan $^{\circledR}$ & 0.4 \\
Nevimune $^{\circledR}$ & 0.5 \\
Nevirapine & 0.6 \\
Nevirapine & 0.7 \\
Nevirapine & 0.4 \\
Abacavir sulfate & 0.6 \\
Abacavir sulfate & 0.8 \\
Abacavir sulfate & 0.9 \\
Estiva $-600^{\circledR}$ & 0.5 \\
Aviroz & 0.5 \\
\hline
\end{tabular}

Table 3. Results of disintegration assays with the studied drugs.

\begin{tabular}{cc}
\hline Specialties & Observed time in minute \\
\hline Abacavir sulfate & 4 \\
Abacavir sulfate & 10 \\
Abacavir sulfate & 10 \\
Aviroz $^{\circledR}$ & 13 \\
Estivan $^{\circledR}$ & 12 \\
Nevipan $^{\circledR}$ & 10 \\
Nevimune $^{\circledR}$ & 11 \\
Nevirapine & 12 \\
Nevirapine & 10 \\
Nevirapine & 12 \\
\hline
\end{tabular}



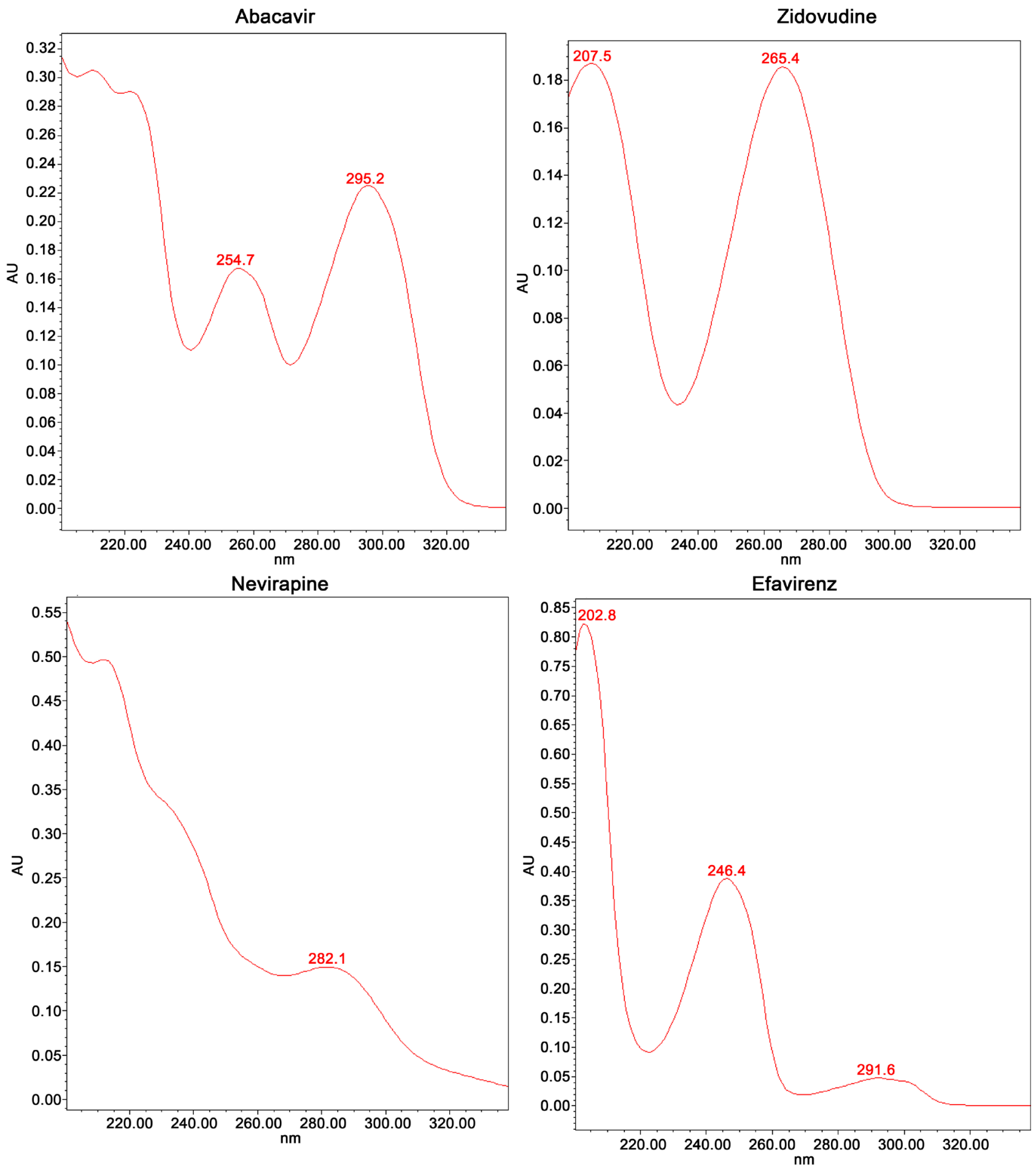

Figure 1. UV-Spectrum obtained for the studied molecules.

Table 4. In all cases, $\mathrm{R}^{2}$ is close to 1 . These different molecules show good adjustment to the calibration line obtained meaning that there is a correlation between the introduced concentration and the analytical response represented by the absorbance. The calibration lines are validated, they were then used to determine concentrations such as $x=\frac{Y-b}{a}$ and content of active substances in 
Table 4. Dosage results of studied drugs.

\begin{tabular}{|c|c|c|c|c|}
\hline Specialties & $\begin{array}{l}\text { Equation of } \\
\text { the lines }\end{array}$ & $\mathbf{R}^{2}$ & $\begin{array}{c}\% \pm \text { standard } \\
\text { deviation }\end{array}$ & Decision \\
\hline Abacavir sulfate & $Y=0.038 X+0.153$ & 0.998 & $105 \% \pm 0.12 \%$ & Conformed \\
\hline Abacavir sulfate & $\mathrm{Y}=0.038 \mathrm{X}+0.196$ & 0.998 & $105 \% \pm 0.67 \%$ & Conformed \\
\hline Abacavir sulfate & $\mathrm{Y}=0.039 \mathrm{X}+0.001$ & 0.999 & $101 \% \pm 0.78 \%$ & Conformed \\
\hline Aviroz ${ }^{\circledR}$ & $\mathrm{Y}=0.028 \mathrm{X}+0.0241$ & 0.994 & $107 \% \pm 0.45 \%$ & Conformed \\
\hline Estiva $600^{\circledR}$ & $\mathrm{Y}=0.039 \mathrm{X}+0.0001$ & 0.999 & $101 \% \pm 0.56 \%$ & Conformed \\
\hline Nevipan ${ }^{\circledR}$ & $\mathrm{Y}=0.034 \mathrm{X}+0.010$ & 0.998 & $99 \% \pm 0.89 \%$ & Conformed \\
\hline Nevimune $^{\circledR}$ & $\mathrm{Y}=0.28 \mathrm{X}+0.20$ & 0.998 & $94 \% \pm 0.78 \%$ & Conformed \\
\hline Nevirapine & $\mathrm{Y}=0.014 \mathrm{X}+0.219$ & 0.986 & $115 \% \pm 0.90 \%$ & Non Conformed \\
\hline Nevirapine & $\mathrm{Y}=0.032 \mathrm{X}+0.001$ & 0.995 & $103.6 \% \pm 0.56 \%$ & Conformed \\
\hline Nevirapine & $\mathrm{Y}=0.028 \mathrm{X}+0.020$ & 0.990 & $97.5 \% \pm 0.87 \%$ & Conformed \\
\hline
\end{tabular}

the samples [14]. A molecule analyzed out of ten (Nevirapine of Strides Arcolab Limited) is non-compliant in relation to the dosage of the active ingredient. This molecule is overdosed (115\%) which is a poisoning threat to patients.

These results are similar to those described in our environment [6], ARVs distributed in Kinshasa are of good quality, but there is still 1 set that captures the attention. Hence the need to widely implement quality control of ARVs.

\section{Conclusion and Perspective}

The objective of this study was to monitor the quality of antiretroviral medicines presented in non-combined form distributed in Kinshasa using UV-Visible spectrophotometry. The molecules used for this study are: Abacavir, Efavirenz, Nevirapine and Zidovudine.

The results obtained from the 10 analyzed molecules show that all these products contain the active ingredients stated and satisfy to friability testing and disintegration of tablets. However, a molecule (10\%) is non-compliant in accordance with dosing tests, which poses a risk of toxicity for the patient. This demonstrates the need for quality control of ARVs prior to distribution in Kinshasa.

\section{Acknowledgements}

The authors acknowledge the financial support for CCD to JK Mbinze. The LAPHAKI and AVEPHARMA laboratories are also thanked for their frank cooperation.

\section{References}

[1] Yeni, P., et al. (2010) Prise en Charge Médicale des Personnes Infectées par le VIH, Rapport. Recommandation du groupe d'experts du Ministère de la Santé et des Solidarités, République Française. 
[2] Gross, O. (2006) Programme OMS de pré-qualification des Antirétroviraux, Antipaludiques et Antituberculeux. Médecine Tropicale, 66, 549-551.

[3] Habyalimana, V., Kalenda, N., Dispas, A., Mbinze, J.K., Kadima, J.L., Lebrun, P., Hubert, P. and Marini, R.D. (2014) Generic Screening Chromatographic Methods to Fight against Poor Quality Medicines. Spectra Analysis, 298, 30-36.

[4] Mbinze, J.K., Nsangu, J.M., Maghe, E., Kobo, S., Mwanda, R., Mulumba, G., Bolavie, J.B., Bayebila, T.M., Borive, M.A., Hubert, Ph. and Marini, R.D. (2015) Application of Total Error Strategy in Validation of Affordable and Accessible UV-Visible Spectrophotometric Methods for Quality Control of Poor Medicines. American Journal of Analytical Chemistry, 6, 106-107. https://doi.org/10.4236/ajac.2015.62010

[5] Kamangu, N.E., Kalala, N.H. and Mesia, K.G. (2012) Profile of Antiretroviral Treatment Centers in Kinshasa, Democratic Republic of Congo. Proceedings of the 1 st Conference of the African Society of Laboratory Medicine, December, Poster 388.

[6] Kamangu, N.E., Kalala, N.H. and Mesia, K.G. (2014) Analyse des Antirétroviraux distribués à Kinshasa: Étude préliminaire. Revue Congolaise des Sciences, 1, 152 159.

[7] Sarkar, M., Khandavilli, S. and Panchagnula, R. (2006) Development and Validation of RP-HPLC and Ultra Violet Spectrophotometric Methods of Analysis for the Quantitative Estimation of Antiretroviral Drugs in Pharmaceutical Dosage Forms. Journal of Chromatography B: Analytical Technologies in the Biomedical and Life Sciences, 830, 349-354. https://doi.org/10.1016/j.jchromb.2005.11.014

[8] Anbazhagan, S., Indumathy, N., Shanmugapandian, P. and Sridhar, S.K. (2005) Simultaneous Quantification of Stavudine, Lamivudine and Nevirapine by UV Spectroscopy, Reverse Phase HPLC and HPTLC in Tablets. Journal of Pharmaceutical and Biomedical Analysis, 39, 801-804. https://doi.org/10.1016/j.jpba.2005.04.044

[9] Sharada, C.H., Channabasavaraj, K.P. and Tamizh Mani, T. (2010) Development of a Spectrophotometric Method for the Quantitative Estimation of Zidovudine Concentration in Bulk and Pharmaceutical Dosage Forms. KMITL Science and Technology Journal, 10, 1-8.

[10] EuropeanPharmacopoeia 8.0. www.online6.edqm.eu/ep800/

[11] Traore, A.S. (2005) Mise au point des méthodes d'identification et de dosage des médicaments antirétroviraux au Mali. Thèse doctorale. Faculté de Médecine, de Pharmacie et d'Odonto-Stomatologie.

[12] British Pharmacopoeia. https://www.pharmacopoeia.com

[13] Buri, P. (1983) Mesure de la vitesse de dissolution pour l'amélioration et le contrôle de la qualité des médicaments. Journal of Pharmaceutical and Biomedical Analysis, 1, 393-402. https://doi.org/10.1016/0731-7085(83)80054-5

[14] The International Pharmacopoeia $6^{\text {th }}$ Edition. www.apps.who.int/phint/fr/p/about/ 
Submit or recommend next manuscript to OALib Journal and we will provide best service for you:

- Publication frequency: Monthly

- 9 subject areas of science, technology and medicine

- Fair and rigorous peer-review system

- Fast publication process

- Article promotion in various social networking sites (LinkedIn, Facebook, Twitter, etc.)

- Maximum dissemination of your research work

Submit Your Paper Online: Click Here to Submit

Or Contact service@oalib.com 